\title{
"RYTUAŁY RODZINNE” WOBEC ŚMIERCI W FILMIE
}

Sytuacja śmierci dotyka całą rodzinę. Zmusza do utworzenia nowych relacji $\mathrm{w}$ niej i przede wszystkim odwagi w spojrzeniu na wszystkich uczestników życia rodzinnego dotkniętych traumą. Chcę przyjrzeć się rodzinnym rytuałom oraz postawom przyjmowanym wobec śmierci $\mathrm{w}$ filmie 33 sceny z życia Małgorzaty Szumowskiej i filmach, gdzie rodzina nie jest na pierwszym planie opowieści o śmierci.

Współczesny reżyser filmowy, decydując się na dyskurs śmierci, a także podejmując się pisania o śmierci, staje przed trudnym zadaniem. Musi rozważyć, jak pozyskać widza do specyficznego tematu. Trudność wynika z nadmiaru obecności przemocy i śmierci właśnie (zwłaszcza w przekazach medialnych), bogactwie samych obrazów filmowych, które bezpośrednio lub pośrednio dotykały śmierci filmowo. Zdaję sobie sprawę, że przywołując pewne tytuły, tworzę subiektywną listę filmów dotykających wspomnianego problemu: Siódma pieczęć (1957) i Szepty i krzyki (1972) Ingmara Bergmana, Bez końca (1984) Krzysztofa Kieślowskiego, Życie jako śmiertelna choroba przenoszona droga ptciowa (2000) Krzysztofa Zanussiego, Pokój syna (2001) Nanniego Morettiego, Inwazja barbarzyńców (2003) Denysa Arcanda, Czas, który pozostat (2005) François Ozona, Pożegnania (2008) Yôjirô Takity, Code Blue (2011) Urszuli Antoniak oraz 33 sceny z życia Małgorzaty Szumowskiej - film, który stał się pretekstem do napisania tego artykułu.

Co może łączyć wymienione filmy? Czy tylko temat śmierci? Przecież nie wszystkie z nich temat ten uczyniły głównym. Czy są to dzieła wybitne, dlatego więc znalazły się na tej liście? Niektóre z nich mogłyby spełniać kryteria arcydzieła, inne obciążone są retoryką publicystyczną, wpisane w bieżące 
dyskusje o jakości życia, a niektóre z nich nie uchroniły się przed egzaltowaną narracją i estetycznym szarżowaniem. Filmy te, po pierwsze, uruchamiają stałą fascynację tematem śmierci obecnym $w$ każdej kulturze, $w$ różnym nasileniu, różnorodnym w opisie, przyciągającym bogactwem symboliki. Po drugie, wymienione filmy $\mathrm{w}$ większości akcentują przesunięcie dyskursu o śmierci z przestrzeni społecznej ku indywidualnemu podmiotowi. Tak jest w przypadku Bez końca Kieślowskiego, Życie jako śmiertelna choroba przenoszona droga ptciowa Zanussiego, Czas, który pozostat Ozona oraz Pokój syna Morettiego. Natomiast Inwazja barbarzyńców i Code Blue są refleksją o kondycji społeczeństwa ze śmiercią w tle, gdzie znów zasadne jest pytanie o granice wolności, decydowania o własnej śmierci; 33 sceny z życia Szumowskiej, podobnie jak starszy film Bergmana Szepty i krzyki, przesuwa kamerę z cierpienia umierającego ku sytuacji rodziny w momencie wiedzy o zbliżającej się śmierci.

Na te pierwsze potrzeby odpowiedział Bergman w Siódmej pieczęci, przedstawiając rycerza dzielnie zasiadającego do dysputy ze śmiercią, a w Szeptach $i$ krzykach brutalnie pokazując puste gesty i rytuały współczucia rodziny wobec umierającej Agnes i wycofania rytuału pożegnania zmarłego z obszaru wspólnie przeżywanego przez rodzinę, wspólnotę. O schowaniu w przestrzeni społecznej rytuału pożegnania w kulturze europejskiej pisze francuski historyk, Philippe Ariès, w swojej książce Rozważania o historii śmierci:

Dziś nie pozostało już nic ani z przeczucia zbliżającego się końca, jakiego każdy doznaje albo powinien doznawać, ani też z uroczystej ceremonii towarzyszącej śmierci. To, co niegdyś miało być wiadome, zostaje przemilczane to, co miało być uroczyste, odbywa się w ukryciu'1.

O wycofywaniu śmierci z ceremoniału publicznego, a doświadczania jej w sposób intymny, opowiadają w swoich filmach Kieślowski i Zanussi. Te filmy dzieli epoka, i w kontekście społecznym, i artystycznym, zbliża je natomiast przesunięcie doświadczania śmierci w sferę prywatną, intymną. Urszulę, bohaterkę filmu Bez końca, poznajemy w momencie pierwszych dni żałoby. Strata męża jest tak silna, że nic i nikt nie jest w stanie zagoić ran, nawet zaangażowanie $\mathrm{w}$ proces młodego robotnika, którego obrońcą był zmarły mąż, czy odnowienie kontaktów z przyjacielem męża. Urszula nawet nie szuka pomocy. Wie doskonale, że nie zagoi ran. Wybiera śmierć samobójczą, pozostawiając syna. Pomijając cały kontekst społeczny, uruchamiany często w trakcie analizy tego filmu, czyli ukazanie letargu Polski po stanie wojennym, ciągnące się procesy opozycji czy brak podstawowych środków do życia - Kieślowski dotknął w tym filmie tabu śmierci samobójczej. W latach 80. XX wieku silnym argumentem walki z systemem było odnoszenie się do wartości, które sym-

${ }^{1}$ P. Ariès, Rozważania o historii śmierci, przeł. K. Marczewska, Oficyna Naukowa, Warszawa 2007, s. 255. 
bolizował Kościól, najważniejszy oponent wobec władz komunistycznych, czynnik integrujący niepokornych wobec władzy. Kieślowski zaproponował inne proporcje w opisie pejzażu lat 80. i podobnie jak w Amatorze, skierował kamerę na jednostkę, na konkretną twarz, na jej ból i to jej pozostawił rozwiązywanie problemów bez uciekania się do najwyższych instancji, strażników respektowania wartości. Gest największej rozpaczy i wolności, dla niektórych samowoli, wybór śmierci samobójczej pozostawił do decyzji swojej bohaterki. W swoim studium o samobójstwie Stefan Chwin pisze:

W społecznościach silnie zintegrowanych, które mają mocne poczucie „własności”, to znaczy traktują jednostkę jako integralną cząstkę organizmu zbiorowego, śmierć samobójcza bywa chętnie semantyzowana w kategoriach policyjno-militarnych jako rodzaj zdrady czy dezercji, w ostateczności uznawana za kryminalne wykroczenie, godne najwyższych kar. (...) Samobójca jako „zdrajca” grupy, „dezerter" tchórzliwie uciekający z pola bitwy, jaką społeczeństwo toczy w wojnie z naturą o swoje przetrwanie na Ziemi, tchórz porzucający wojskowy posterunek, na którym został postawiony przez Boga i władzę państwową (... $)^{2}$.

Natomiast bohater filmu Krzysztofa Zanussiego Życie jako śmiertelna choroba przenoszona droga ptciowa, Tomasz Berg, sam jest przed najtrudniejszym, ostatecznym doświadczeniem własnej śmierci. Mamy fachowca od umierania. Sam asystował przy śmierci, ale te wszystkie doświadczenia medyczne nie dają mu przewagi nad innymi. Lekarzowi z takim doświadczeniem zawodowym jest chyba trudniej. Jak zwykle u tego twórcy mamy uruchomioną refleksję o kontekście duchowym bohatera. Jest także w tym filmie, podobnie jak we wcześniejszych filmach tego artysty, ufność, że wyruszenie w poszukiwaniu siebie, swojej duchowości, ma sens, jak choćby w Imperatywie. I to, co jest charakterystyczne dla tego twórcy - prezentacja dialogujących ze sobą reprezentantów odmiennych postaw. Tutaj o sens cierpienia spór toczy Tomasz Berg z księdzem Markiem.

Temat śmierci towarzyszy Zanussiemu od początku jego twórczości, choćby w filmie dyplomowym z 1966 roku - Śmierć prowincjała, potem w Iluminacji i Spirali. Wcześniej umieściłam film Życie jako śmiertelna choroba... w przestrzeni filmów ukazujących śmierć w ciszy, w intymności. Tomasz Berg nie ucieka $\mathrm{w}$ panice przed śmiercią $\mathrm{w}$ moc technologii medycznej uśmierzającej ból, czasem przedłużającej życie, cierpienie. Choć brzmi to patetycznie, staje wobec śmierci twarzą w twarz. Jak rycerz w Siódmej pieczęci. Nie jest wolny od lęku - jak wszyscy boi się bólu, samotności. Pewnie jest to zasługą wybitnego aktora Zbigniewa Zapasiewicza, że jego bohater jest wiarygodny $w$ tej walce o dobry kres życia. Oddaje to krótka scena, w Paryżu, w kawiarni; zarejestrowane spojrzenie twarzy aktora-bohatera, który zdaje sobie sprawę, że

2 S. Chwin, Samobójstwo jako doświadczenie wyobraźni, Wydawnictwo Tytuł, Gdańsk 2011, s. 53 . 
to ostatnie zawody z losem, Bogiem. Bohater wie, że w tej ostatniej drodze samotność odczuwa się najbardziej, ale nie podejmuje histerycznych, sentymentalnych prób zbliżenia się do innych, zbratania się przed śmiercią. $\mathrm{W}$ dodatku, nie zabiegając o to, zdąży stać się mistrzem dla adepta medycyny Filipa i jego dziewczyny. Ale w momencie najważniejszym pozostaje sam. Wobec takich ludzi, samotnych wobec śmierci, z "misją" przychodzi bohaterka Marian (Bien de Moor) w Code Blue w reżyserii Urszuli Antoniak. Jest siostrą $\mathrm{w}$ śmierci, pielęgnuje, myje umierających, a dla zachowania ich w pamięci, śladu ich obecności, gromadzi w domu przedmioty, które do nich należały. Czasem jej pomoc przekracza zwykłą opiekę i pielęgnację - wstrzykuje „lek” na odejście, nawet mężczyźnie, którego gesty błędnie odczytuje. Nie jest to film o eutanazji i nie jest to film tylko o umierających. Jest refleksją o głębokiej samotności bohaterki. Jedną z form zagłuszania samotności jest asystowanie śmierci. To na tym oddziale szpitalnym, w hospicjum, obcy ludzie połączeni jedną trasą ku śmierci stają się jej rodziną. To ona dokonuje rytuału pożegnania, w którym nie uczestniczy rodzina. Philippe Ariès pisze:

Śmierć w szpitalu przestała być (...) rytualną ceremonią, której przewodniczy umierający, otoczony rodziną i przyjaciółmi. Stała się zjawiskiem technicznym, następującym w wyniku zaprzestania zabiegów leczniczych, a więc - co przyznaje się mniej lub bardziej otwarcie - wyniku decyzji lekarza i zespołu szpitala. W większości przypadków zresztą umierający jest już od dawna nieprzytomny. Śmierć została rozłożona na części, podzielona na wiele krótkich etapów i w ostatecznym rozrachunku nie wiadomo, kiedy następuje rzeczywista śmierć - czy jest nią utrata świadomości, czy zatrzymanie oddechu... Wszystkie te drobne, ciche śmierci zastąpiły i przesłoniły wielkie, dramatyczne widowisko śmierci i nikt już nie ma ani siły, ani cierpliwości, by tygodniami oczekiwać chwili, której sens po części się zagubił ${ }^{3}$.

W filmie Denysa Arcanda Inwazja barbarzyńców ${ }^{4}$, ucieczka od działań bezdusznego szpitala jest możliwością przeżycia śmierci we wspólnocie - to film nie tylko o umieraniu i indywidualnej decyzji o "jakości umierania"; brzmi to obcesowo, technicznie, ale jest to przede wszystkim spojrzenie z dystansem, bo perspektywa śmierci taki dystans na "pokoleniu 68” wymusza. Na ile hasła braterstwa z tamtych dni jeszcze coś dla tego pokolenia znaczą? Syn umierającego Remy' ego, Sebestien, organizuje ojcu nie tylko wyjazd w domowe zacisze natury, ale przede wszystkim udaje mu się zgromadzić przyjaciół z młodości ojca. Braterstwo „pokolenia 68” nie jest pustym rytuałem. Towarzyszą przyjacielowi aż do ostatniej kropli „leku na odejście”. Tutaj śmierć przychodzi po udanym, choć burzliwym życiu: udanym w sensie wierności ideałom młodości i marzeniom.

\footnotetext{
${ }^{3}$ P. Ariès, Rozważania..., dz. cyt., s. 93.

${ }^{4}$ Film ten analizuję $\mathrm{w}$ artykule Czas między życiem $i$ śmiercia - motyw śmierci w filmach: „Inwazja barbarzyńców” i "Czas, który pozostat” ([w:] J. Kolbuszewski (red.), Problemy wspótczesnej tanatologii, t. 10, Wrocławskie Towarzystwo Naukowe, Wrocław 2006, s. 383-386).
} 
W filmie François Ozona Czas, który pozostat, śmierć przychodzi nagle, o diagnozie i perspektywie szybkiej śmierci dowiaduje się młody, wzięty fotograf mody, Romain. Jego sposobem na dotarcie do tego momentu jest zerwanie relacji z najbliższymi. Jest $\mathrm{w}$ stanie podzielić się tym tylko ze swoją babką, która jest mu teraz bliska, bo podobnie jak on jest bliska kresu. Przejmującą jest scena wieńcząca opowieść o umierającym młodym człowieku - Romain umiera na plaży wśród plażowiczów. Podobnie jak Tomasz Berg z filmu Zanussiego nie oszukuje się, że przeżywanie tego z kimś uchroni go przed lękiem, strachem. W filmie Ozona śmierć wdziera się w życie młodości, która obiecuje tyle możliwości, natomiast w dziele Pokój syna Morettiego $^{5}$ to tragiczny wypadek podczas nurkowania zabiera rodzinie nastoletniego syna. Moretti, reżyser i odtwórca roli ojca, oprócz pokazania wszystkich etapów przeżywania żałoby ukazał pustkę rytuałów religijnych, w których uczestniczy rodzina po śmierci syna. Nawet przytaczane przez kapłana słowa z Ewangelii, które cytuje się ku pokrzepieniu żałobników, nie przynoszą ukojenia, wręcz przeciwnie - wzmagają bunt ojca. Reżyser ukazuje także, jak trudno współcześnie przeżywać żałobę. Autor książki Tryumf śmierci. Antropologia żałoby, Alfonso di Nola, pisze o tym problemie:

W miastach anonimowość kryzysu opłakiwania, nieprzeżywanego razem ze zbiorowością i niepodlegającego cenzurze grupy, sprawia, że żałoba najczęściej przebiega bez odwołania się do jej form etykietalnych i, z wyjątkiem bardzo rzadkich przypadków, bez otwartego manifestowania jej przez rodzinę. Są to tendencje o ambiwalentnym nacechowaniu, gdyż chociaż z jednej strony ograniczają cierpienie do strefy prywatnej i osobistej, ale z drugiej pozbawiają je wsparcia społeczności, które jest, jak wiemy, bardzo użyteczne w procesie przezwyciężania żalu za zmarłym ${ }^{6}$.

Inny aspekt śmierci w rodzinie ukazuje japoński film Pożegnania - tutaj jako widzowie podglądamy najtrudniejszy moment $\mathrm{w}$ sytuacji rodzinnej: kontakt z martwym ciałem. Nie jest to jednak opowieść, która obezwładnia grozą obecności zwłok. Śledzimy historię młodego małżeństwa. Bohater Daigo Kobayashi, wiolonczelista, właśnie stracił pracę w tokijskiej orkiestrze i przenosi się z żoną do rodzinnej Sakaty. Szuka pracy i udaje mu się zatrudnić w firmie pogrzebowej jako nokanski, czyli osoba, która składa ciało zmarłego do trumny; osoba taka określana jest jako towarzysz podróży. Daigo nie wyjawia żonie, gdzie znalazł pracę - określa to jako szeroko rozumiane organizowanie podróży, imprez. W sposób subtelny, a czasem humorystyczny reżyser ukazuje stosunek społeczeństwa do pracy ludzi, którzy są niezbędni

${ }^{5}$ Film ten analizuję w artykule Kres męstwa - doświadczenie śmierci i żałoby w filmie "Pokój syna" Nanniego Morettiego ([w:] J. Kolbuszewski (red.), Problemy wspótczesnej tanatologii, t. 9, Wrocławskie Towarzystwo Naukowe, Wrocław 2005, s. 473-477).

${ }^{6}$ A.M. di Nola, Tryumf śmierci. Antropologia żałoby, przeł. M. Woźniak, Universitas, Kraków 2006, s. 56. 
w tym ostatnim etapie pożegnań. Towarzyszy tej profesji pewne zażenowanie, zawstydzenie. Małżeństwu bohatera grozi nawet rozpad z powodu braku akceptacji żony wobec nowego fachu męża. Daigo dzięki swojemu szefowi odkrywa tymczasem powołanie. Wie, że nie jest to zwykła praca, uświadamia to sobie każdego dnia, czasem bardzo boleśnie, zwłaszcza gdy trzeba wyciągnąć z mieszkania rozkładające się ciało. Czuje jednak, jak wielką pomoc oferuje rodzinom zmarłych, przygotowując ciała zmarłych do ostatniej podróży. Sceny rodzinnych pożegnań, towarzyszenie podczas obmycia zwłok, wykonywania makijażu, oddane są z japońską estetyczną subtelnością. Ostatnia posługa wobec zmarłych i ich rodzin ukazana w tym filmie wydaje się kolejną dziedziną sztuki japońskiej, jak tworzenie ogrodów czy układanie kwiatów.

Wspomniałam wcześniej o braku akceptacji społecznej wobec pracy, gdzie istotą jest kontakt ze zwłokami. Ten strach udziela się nie tylko Japończykom. Wspomniany Alfonso di Nola, głównie badając zachowania wobec śmierci w kulturach europejskich, zwraca uwagę: „Bardzo istotną cechą nieboszczyka jest jego głęboka ambiwalentność, a nawet poliwalentność. Świat żywych czuje w stosunku do niego dwojakie obciążenie psychiczne, co przekłada się na zachowania skrajne i pełne sprzeczności"7. Szczególnie przejmujące są sceny pożegnań młodych dziewcząt, rozpaczy rodzin, ale też nie brakuje ofiar wypadków drogowych, szalejących młodzieńców na motorach. Jest cały przekrój społeczny i „przekrój” reakcji na śmierć. Pojawia się pytanie, dlaczego przywołuję ten nieco egzotyczny film, z elementami komediowymi, i zestawiam z omówionymi już filmami czy kameralnym dramatem polskiej reżyserki Małgorzaty Szumowskiej. Film Szumowskiej jest nie tylko opowieścią o śmierci, agonii, żałobie. Jest w nim opowieść rodzinna, momentami zabawna i ciepła, a czasem chłodna obserwacja rozkładu rodziny. Bohater Pożegnań będzie towarzyszem podróży szczególnej osoby - ojca, który kontakty z rodziną zerwał już dawno. Nie chce uczestniczyć w tym wyjątkowym rytuale. Podejmuje się go dopiero po długich namowach żony, która zdaje sobie sprawę z konieczności uszanowania cyklu rodziny, następstwa pokoleń; aby mogło narodzić się nowe życie, nowa rodzina, należy z szacunkiem pożegnać przeszłość, którą symbolizuje tutaj ojciec. Reżyser ukazuje sytuację, która jest trudna zwłaszcza dla dziecka, najtrudniejszym bowiem pożegnaniem jest pożegnanie rodziców. Zabierają oni ze sobą cały świat, który pokazali dając życie, w chwili śmierci zabierając go i nakazując stworzenie własnego. Jedna $z$ ostatnich scen filmu Takity, przygotowanie ciała ojca do podróży, ukazuje to, co nieuchronne, ale co przynosi ukojenie po stracie. Jak pisze Michel Vovelle:

Śmierć przeżywana to przede wszystkim cała sieć gestów i rytuałów, towarzyszących przebiegowi śmiertelnej choroby aż do agonii, grobu i dalej w zaświaty... Wyraża się

7 Tamże, s. 243. 
ona najpierw w praktykach pogrzebowych, które miały człowieka pokrzepić: w owych magicznych, religijnych i świeckich zabiegach, za pomocą których próbowano zawsze śmierć obłaskawić, nadając rytuałowi ostatniego przejścia, pogrzebowi, pochówkowi i żałobie strukturę, w której odbijała się niekiedy narzucona postawa wobec śmierci, a częściej dawało się odczytać nawarstwione ślady rozmaitych tradycji ${ }^{8}$.

Małgorzata Szumowska skrupulatnie ukazuje wszystkie fazy egzystencji rodziny skonfrontowanej z chorobą, świadomość znikomej szansy na wyzdrowienie i samą agonię. Samo wybranie rodziny patchworkowej (córka z pierwszego związku, wspólna córka, syn męża z pierwszego związku i „zaadoptowany" towarzysko zięć) jest już ciekawym zabiegiem przyjrzenia się rodzinie, w której nikt nie ukrywa swoich egoizmów, nadętych artystycznie ego. Jest najstarsza córka (Iza Kuna) z ubytkami miłości matki i w związku z tym pretensjami do niej, nie milknącymi w obliczu śmierci, ale narastającymi, gdy koniec jest bliski. Jest młodsza siostra, pozornie dojrzała, bardziej chyba artystycznie i pozornie spełniona w małżeństwie (Julia Jentsch). Jest też jej mąż (Maciej Stuhr), który - ma się wrażenie - był w życiu tej rodziny od zawsze, chyba na zasadzie przyjaciela, pomocnika, kumpla; jest też tajemniczy przyjaciel od interesów artystycznych, obserwator (Peter Gantzler), który zaistnieje w sytuacji krytycznej. I są oczywiście rodzice, symbiotyczna para, wspaniały duet (Małgorzata Hajewska i Andrzej Hudziak). Para konkurująca ze sobą w grze o to, które dziecko, z którego małżeństwa, poświęca im więcej czasu i uwagi. Nie tylko sytuacja umierającej matki i jej perspektywa jest tu istotna. Cała rodzina poddana jest obserwacji, a szczególnie istotna jest tu funkcja najmłodszej w rodzinie artystki. To ciekawy zabieg, że śledzimy całą historię postępów śmierci właśnie z perspektywy tej młodej osoby, która nie wie nic o śmierci, bo doświadcza jej teraz, nagle. Nie jest wyposażona w wiedzę, jak należy się zachować, jak rozmawiać z matką, ojcem. Błądzi, ale jest naturalna, w przeciwieństwie do starszej siostry, którą brzydzi fizjologia śmierci, drażni matka, którą trzeba się zajmować na zasadzie obowiązku dziecka.

W tych scenach oporu starszej córki wobec wspólnego bycia z chorobą matki, degradacją jej ciała i umysłu, można odnaleźć pewną zbieżność opisu choroby z tym z Szeptów i krzyków Bergmana, gdzie reżyser odważnie pokazał niechęć rodziny do umierającej, odrzucanie obowiązku towarzyszenia jej w cierpieniu, obrzydzenie wobec jej śmiertelnie chorego ciała. Bergman ukazał także, że to pielęgnowane przez chrześcijaństwo towarzyszenie członkowi rodziny w śmierci jest bezwzględnie odrzucanym obowiązkiem, niećwiczonym w momencie kresu. Podobnie u Szumowskiej nie reaktywuje się przećwiczonych w chrześcijaństwie rytuałów towarzyszenia. Nie dlatego, że

${ }^{8}$ M. Vovelle, Historia ludzi w zwierciadle śmierci, przeł. M. Ochab, [w:] Wymiary śmierci, wybór i słowo wstępne S. Rosiek, słowo/obraz terytoria, Gdańsk 2010, s. 36. 
umierająca jest niewierząca, ale że uczestnicy tych rytuałów nie potrafią nic wnieść. Oddaje to scena wezwania byłego młodego księdza do modlitwy. On sam zapomniał już formuły, a rodzina nawet nie próbuje udawać, że się modli. Sam pogrzeb jest autentyczną chwilą wytchnienia po udręce szpitalnego asystowania przy śmierci. Szumowska nie jest ironiczna, cyniczna wobec rytuałów pożegnań, zachowywania się w żałobie. Odważnie pokazuje nieracjonalne zachowania wobec śmierci, które są możliwe, bo tak reaguje organizm na stres. Bo strach przed śmiercią już się przekroczyło $w$ momencie śmierci najbliższych. Jest to też film o przyspieszonym kursie dorosłości, którą funduje w śmierć rodziców. Nic już nie ocaleje z dzieciństwa w chwili śmierci, trzeba budować siebie na nowo, a młode małżeństwo (Jentsch i Stuhr) przyzwyczaiło się do ustalonego porządku, egzystowania jak wyrośnięte dzieci. Szumowska nie akcentuje roli rodziny w pożegnaniu umierającego. Nie są ważne relacje rodzinne, aby jakość tej specyficznej wspólnoty bólu była dobra. Jak we wszystkich prezentowanych filmach, nikt i nic nie jest pewne w konfrontacji ze śmiercią. Pewne jest, że zjawi się nieproszona i zwrot ku pewnym rytuałom będzie jedynym pocieszeniem.

\author{
„Family rituals" in the face of death in films \\ Sum mary
}

In the article Family rituals in the face of death the author analyzes films from the perspective of the experience of a family confronted with death. The author is interested in what family rituals are still used at this time and what actions have been abandoned.

The presented films demonstrate fascination with the topic of death, which is present in every culture with different intensity, by means of various descriptions which are attractive because they are filled with the richness of symbols. The majority of these films emphasize a shift in the discourse about death in social space towards an individual subject.

The author wanted to observe and show the moment when the community experience of death and mourning was given up and the ritual passed into the hands of specialized institutions. 